\title{
Theoretical and Practical Aspects of Arms Trafficking
}

\author{
Kofanov Andrii \\ PhD of Juridical Sciences, Associate Professor, Professor of Department of \\ Forensic Support and Forensic Expertise of the National Academy of Internal \\ Affairs, Kiev, Ukraine \\ ORCIDID0000-0002-5242-2518_kofanov_andrey@ukr.net
}

Anufriieva-Injukova Victoria

Master of sports of Ukraine on ballistic shooting, Kiev, Ukraine

Victoria.anufrieva@gmail.com

\begin{abstract}
Kulyk Maryna
PhD of Juridical Sciences, Associate Professor of Forensic Support and

Forensic Expertise of the National Academy of Internal Affairs, Kiev, Ukraine ORCID ID 0000-0003-1373-6749 coolss777@ukr.net
\end{abstract}

\section{Tereshchenko Yuliia}

PhD of Juridical Sciences, Professor of Criminal Law Disciplines and Operative and Investigative Activities of the Precarpathian Department of the

National Academy of Internal Affairs, Kyiv, Ukraine ORCID ID 0000-0002-5353-0887 vladysikter@ukr.net

\section{Kutsyi Roman}

PhD of Juridical Sciences, Senior Teacher of Criminal Law Disciplines and Operative and Investigative Activities of the Precarpathian Department of the

National Academy of Internal Affairs, Kyiv, Ukraine ORCID ID 0000-0002-1979-7019 romakrv2009@ukr.net

\begin{abstract}
The article deals with general analysis of the modern state of ensuring rights of Ukrainian citizens by law enforcement authorities in the sphere of firearms turnover and questions of establishment, perspectives of development The Firearms Act of Ukraine. There are deep social, economic and political transformations in Ukraine nowadays. It is necessary to declare, that progressive processes of construction of the legal democratic state, except the positive ones, have unavoidable adverse effects. So, the number of persons and refugees who have no means of subsistence and constant residences has increased. Accordingly number of crimes has increased, the activity of law enforcement structures have become lower, and they have no means to provide complete protection for private, municipal, state ownership, the rights of the person, as the freedom, honor and dignity of an individual from illegal acts.
\end{abstract}

Key words: The Firearms Act, firearms turnover, the registration and accounting of firearms. 
Introduction In part 2 the article 27 of The Constitution of Ukraine states that "everyone has the right to protect his life and health, and a life and health of other people from illegal infringement" [4]. The constitutional norm has found an embodiment in other branches of the law. Actually, in the article 36 "Necessary defense" The Criminal Code of Ukraine directly states that there is a real opportunity of using this institute with application of the firearms by a person [5]. So, one of the ways of protection of the above-stated human rights is the right of a person to be an owner, carrier and user of firearms.

To be an owner of firearms one person naturally conflicts with the right of life and health of other individuals, because it determines a potential opportunity of using firearms against other individuals. There are many scientists who devoted their works to these questions. Among native scientists are: P.D. Bilenchuk, A.V. Kofanov, O.F. Suljava, Ya.Yu. Kondratev, A.I. Kaplunov, D.A. Koretskyj, V.V. Nazarov, V.I. Antipov, O.I. Rements', L.M. Kononenko, A.S. Matsko, I.V. Bojko, O.M. Pidzharenko, C.O. Nevskij etc.

Strengthening of law is one of the most important functions of the state, which is connected with a wide range of social, economic, political and organizational activities.

Combating the illicit trafficking of firearms has a special place in the warning of crime by law enforcement, because it is characterized by double prevention: in addition to stopping the illegal weapon, it prevents serious consequences that may arise as a result of its unlawful use.

Unfortunately, the number of crimes related to the usage of firearms increases. According to the statistics of the Ministry of Internal Affairs of Ukraine, during the year of 05.2019 410 crimes with firearms involved were committed (including murder (and attempts) - 100), while in 2018 - 311 (including murder (and attempted) - 84) and in 2017 - 311 (including murder (and attempted) - 75). Thus equipment of modern criminals with firearms has brightly expressed the tendency to increase on a background of different international, general social tensions, and also insufficient legitimate appeal of weapons in general $[8,9]$.

In particular, according to the above statistics, staff of Internal Affairs Bodies seized 3080 firearms (including smooth - 314, rifled - 1402, other firearms - 1364) during 
05.2019, while in 2018 - 2974 (including smooth - 313, rifled - 1402, other firearms 1385). So, as we see, the dynamics leaves much to be desired $[8,9]$.

In general, the accounting departments of licensing system Ministry of Interior Affairs of Ukraine has more than 1841 objects with the weapon, which is stored and used 59570 firearms and more than 1650 other objects of the licensing system. In addition, there are approximately 699756 holders of hunting firearms, and about 810995 firearms in use [2]. Of course, controlling all these weapons requires a system of tools, techniques and methods developed and improved in all areas of criminology and criminalistics which are based on studying the investigating and expert practice. These types of practical activities are fixed in legislation. There are many laws that complement each other. But with them there is a certain range of problem questions, such as trafficking of some types of firearms, air weapons and devices for shooting bullets, filled with rubber or similar characteristics missiles of non-lethal action, etc. First of all the most actual and problem question is that for 28 years Ukraine has adopted a very important normative act - The Firearms Act, which regulates turnover of firearms between civil people and satisfies all necessity of the particular statutory objectives.

Legislative control of the ownership and usage of firearms in independent Ukraine began with the adoption of Decree "On ownership of certain types of property" on 17 June 1992 , and Annex number 2 to this Decree, which contained a special order of acquisition of property rights to citizens of certain types of property by the Supreme Council. On October 12, 1992 the Cabinet of Ministers of Ukraine approved the Regulations on the permit system, which is directly involved in the control firearms turnover in Ukraine and is located in the Ministry of Internal Affairs of Ukraine [1, c. 11]. Officially, the legal procedure fixing the trafficking of firearms in Ukraine was completed on August 21, 1998, Order of the Ministry of Ukraine № 622 approved the "Regulations on the order of production, acquisition, storage, transportation and usage of firearms, air and cold weapons, devices of domestic production for shooting bullets, filled with rubber or similar characteristics missiles of non-lethal action, and cartridges and ammunition for the weapons and explosive materials".

This instruction has defined:

1) the task of the Interior to implement the permit system; 
2) order permitting the acquisition, storage, transportation and use of weapons;

3) control for facilities of licensing system;

4) a detailed procedure for the acquisition, storage, security, transportation and use of weapons and military supplies.

Nowadays short-barreled firearms are completely forbidden for the civil. Citizens can buy firearms only for hunting. The barrel of such firearms must not be smaller than $450 \mathrm{~mm}$ long, and the total length must not be smaller than $800 \mathrm{~mm}$ [7].

The short historical analysis of appearing, development and formation of smooth-bore fire-arms in the world allows to pass to us to definition of concept and its classification on fighting, those of special purpose and the hunting smooth-bore fire-arms.

The fighting smooth-bore fire-arms (FSBW) is the weapon with smooth trunks in which kinetic energy of combustion of gunpowder for the ejection of an individual or plural shell which is on arms in armed forces of many countries of the world (the USA, Italy, France, Germany) is used and are specially intended for the decision of fighting and operatively-office problems in the process of which live force of the opponent is destroyed. Thus the elements which attack the opponent are case-shot (usual lead, steel - plated), special arrow-like elements (which initial speed about $800 \mathrm{~m} / \mathrm{s}$ ), bullets. The fighting smooth-bore fire-arms (FSBW) are characterised by following tactic-specifications:

1) the length of a trunk is less than $500 \mathrm{~mm}$ (there are exceptions), weapon total length in position for shooting less than $800 \mathrm{~mm}$;

2) trunk drilling - the cylinder $(0,00 \mathrm{~mm})$;

3) more than 4 cartridges in the shop;

4) special fighting supplies;

5) length of a cartridge chamber 70, 76, 82, $89 \mathrm{~mm}$;

6) presence of a complicated butt, a standard butt;

7) rifle front sight and dioptrical sight;

8) presence of adaptations for fastening of a laser sight, the device of night vision, a lamp-lighter;

9) calibre $10,12,20, .410$

10) quantity of trunks - 1;

11) presence of special markings; 
12) initial speed of flight of a shell - to $820 \mathrm{~m} / \mathrm{s}$;

13) presence of modular systems, a bayonet, the device of low-noise shooting, the fire extinguisher, bore jack;

14) possibility of firing by turns. Unlike fighting the smooth-bore fire-arms of a special purpose are the weapon intended for conducting of special operations and the solution of operatively-service problems in the process of which live force of the opponent is wounded (not mortally).

It is not on arms in Armed forces, and is applied in police, militia, safety public service, special purpose groups. Factors which attack the opponent are the rubber or plastic bullets, a case-shot, substances of lachrymatory or irritating action, a rubber-sticky liquid, incendiary, marking mixes (in grenades) and shells of charges which are used for fighting smooth-bore fire-arms. On tactic-technical characteristics smooth-bore fire-arms of a special purpose are divided into: a) classical and b) universal [14].

The classical smooth-bore fire-arms of a special purpose on the tactic-technical characteristics are intended only for shooting of shells (rubber or plastic bullets or a caseshot, and also the grenades equipped with substances of irritating or lachrymatory action, the rubber-sticky liquid, incendiary, marking mixes). The universal smooth-bore fire-arms of a special purpose on the tactic-technical characteristics are intended to defeat the aim as by shells of classical smooth-bore fire-arms of a special purpose, so by means of fighting supplies for fighting smooth-bore fire-arms, namely lead and steel bullets, a case-shot, arrowlike shells. Thus, speaking about tactic-technical characteristics of classical smooth-bore firearms of a special purpose, it is necessary to ascertain, that tactic-technical characteristics of this weapon differ greatly one from another because of different design features (decision) and different technical standards in the countries-manufacturers.

Characteristic signs of this weapon are: a) the lock which slides and becomes isolated turn of the lock of a larva, or wedge closing; b) the great dispatch-trigger mechanism of hammer, hummer-planger type; drum-type, box-shaped, tubular shop; the length of a trunk fluctuates from $610 \mathrm{~mm}$ to $210 \mathrm{~mm}$; Range of shooting up to $150 \mathrm{~m}$; use of charges of nonstandard calibres as non-standard there is the weapon calibre (KC-23); rather low rate of fire - from 4 shots per minute; charges have as hunting paper or a plastic sleeve with a metal flange, or all-metal. The sleeve is charged by a grenade (gas, incendiary, marking), a rubber, 
plastic bullet or a case-shot; initial speed of flight of a shell - 250-270 m/s. Thus, the smoothbore fire-arms of a special purpose coincides with fighting smooth-bore fire-arms by an action principle (use of kinetic energy of combustion of gunpowder for throwing of an individual or plural shell), but differ with tactic-technical characteristics which concern: length of a trunk (from $610 \mathrm{~mm}$ to $210 \mathrm{~mm}$ ); calibre (non-standard but there are exceptions); the lock which slides and becomes isolated turn of the lock of a larva or cotter connection; the great dispatch-trigger mechanism of hammer; drum-type, box-shaped, tubular shop; small range of shooting (to 150) and initial speed of flight of a charge (250-270 m/s), etc. The cartridges to this weapon by type have the hunting paper or plastic sleeve with a metal flange, which is equipped with a grenade (gas, incendiary), a rubber, plastic bullet or the case-shot.

As to tactic-technical characteristics of universal smooth-bore fire-arms of a special purpose, the following tactic-technical characteristics are typical:

1) calibre 12 or 20 ;

2) the length of a trunk is less $500 \mathrm{~mm}$ (there are exceptions);

$3)$ trunk drilling - the cylinder (0,00 mm.); Over 4 cartridges in shop;

4) special fighting supplies;

5) length of a cartridge chamber 70, 76, 82, $89 \mathrm{~mm}$;

6) presence of the pistol handle; rifle front sight and dioptrical sight;

7) presence of adaptations for fastening of a laser sight, the device of night vision, a lamp-lighter;

8) quantity of trunks - 1;

9) presence of special markings;

10) initial speed of flight of a shell $250-820 \mathrm{~m} / \mathrm{s}$;

11) presence of nozzles for shooting of grenades of 36 and $82 \mathrm{~mm}$.

This weapon is used only in police and groups of a special purpose (Ministry of Internal Affairs) and is intended for conducting special operations and performance of operatively-office problems in the process of which live force of the opponent is injured or destroyed. Versions of this weapon differ one from another in the technical characteristics, different design features (decisions) and technical standards of the countries-manufacturers. 
Taking into account these features it is offered to classify smooth-bore fire-arms of a special purpose into the following two groups:

a) the classical;

b) the universal.

Thus the classical smooth-bore fire-arms of a special purpose on the tactic-technical characteristics are intended only for shooting of shells (rubber or plastic bullets or a caseshot, and also the grenades charged by substances of irritating or lachrymatory action, the rubber-sticky, marking liquid, incendiary mixes). The universal smooth-bore fire-arms of a special purpose on the tactic-technical characteristics are intended for shooting as shells of classical smooth-bore fire-arms of a special purpose (with the help under-calibre nozzles), and fighting supplies to fighting smooth-bore fire-arms (lead and steel bullets, a case-shot, arrow-like elements). By the trunk length the smooth-bore fire-arms of a special purpose (classical and universal) are divided into short-barrelled (length of a trunk to $270 \mathrm{~mm}$ ), midbarrelled (length of a trunk from $270 \mathrm{~mm}$ to $500 \mathrm{~mm}$ ) and long-barrelled (length of a trunk over $500 \mathrm{~mm}$ ). According to the same sign the fighting smooth-bore fire-arms are divided into mid-barrelled (length of a trunk over $270 \mathrm{~mm}$ and to $500 \mathrm{~mm}$ ) and long-barrelled (length of a trunk over $500 \mathrm{~mm})[11,12]$.

Actually, a person who is 21 can own a shotgun and, a person who is 25 can own a rifle. For this it is necessary to do the following:

- to submit a written petition addressed to the head of Internal Affairs Bodies;

- to fill in a card-application;

- to be medically certified of having no contraindications for owning weapons;

- to pass prevention drug inspection;

- to pass exam on material part of firearms and rules of using firearms.

If everything is correct Internal Affairs Bodies give the person a licensee for buying the weapons. The license is valid for a 3-month-period and the purchase of firearms has to be registered within 10 days.

In general, today in our country public relations concerning arms turnover are regulated by nearly 90 legal acts (including laws, orders, decrees, etc.). But they lack the main normative act - The Firearms Act does not yet exist. For instance, in the C.I.S. and in some neighboring countries The Firearms Act was adopted in: the Russian Federation - in 
1993, the Republic of Belarus - in 2001, Latvia -in 2002, the Republic of Moldovain 1994 [1, c. 172].

Of course, a significant number of bills "On the weapons" have been given to the deputies for consideration since 1998 in Ukraine. Based on the results of analysis of the draft laws on firearms, you can draw the following conclusions:

- all submitted bills "On the weapons" need completing;

- in any of them the right of people for ownership and usage of office-routine firearms is not given, and in those cases, for people who have such right the art. 3, 19, 21 and 24 of the Constitution of Ukraine are violated;

- the most constructive is the bill by such deputies as: Chernovetskyj L.M., Rymaruk O.I., Danilchuko O.Yu. and Nedryhaylo V.M. dated by 02.10.2002, the most regulated one is the Bill of Cabinet of Ministers of Ukraine dated by 13.05.98

- it is appropriate to involve the firearms and art experts, historians, lawyers, economists and specialists on certification and criminal expert services in Ukraine to rework the bill.

Only on March 4, 2004, an act number 1171-D was adopted by the Supreme Council of Ukraine in the first reading. Draft Law of Ukraine "About the weapons" number 1171-A was a compromise, combining the most appropriate position privies projects (numbers 1171 (introduced by deputies of Ukraine Karmazin Ju.A, Chernovetskyj L.M., Nechyporuk V.P., Rymaruk A.I., and 1171-2 (submitted by deputies of Ukraine Vinskij J.V., Razvadovskyj V.I., Bul'ba S.S., Korol V.M., Zubov V.S.). The main feature of this Bill is a refuse to provide the citizens a right of ownership of short firearms (pistols and revolvers). Questions about readiness of our society to acquire such weapons, deliberation of all the pros and cons of such a permit is too complicated and therefore deserves a separate study [3, c. 111].

Subsequently, a draft Law of Ukraine "About turnover of non-military weapons" was introduced for consideration to the Supreme Council. It was adopted in first reading on February 9, 2009, a bill number 2105. Authors (Moysyk V.R., Gritsak V.M., Prokopchuk Yu.V., Pudov B.M.). The document offered to reduce the age limit for the right acquisition, possession and usage of fire-smooth-bore hunting firearms, weapons of self-defense by citizens of Ukraine from the age of 21 to 18 and the right to acquire, store, 
carry rifle from the age of 25 to 21 , as well as an expanded list of permitted weapons for possession by citizens of self-defense pistols and revolvers, designed for shooting bullets, filled with rubber or similar characteristics missiles non-lethal action. But on 17.02.2019 the draft Law was presented for replacement. In our view, it is quite appropriate, since the adoption of this draft bill the arms of "self-defense" can become a weapon of "attack"; secondly, a gun that shoots rubber bullets, can be converted to firearm, so, this may lead to outbreaks of crime in society, particularly considering the general level of civilization, the level of culture, the level of aggressiveness in the society and the economic crisis. 15.04.2019 a draft Law of Ukraine "About turnover of non-military weapons" was once again introduced for consideration to the Supreme Council, but it wasn't established as The Firearms Act [15].

Besides, there is an issue that The Firearms Act of Ukraine must be established according to the international requirements. Nowadays our country is the participant of different international programs, such as The United Nations Program on the Illicit Trade in Small Arms and Light Weapons, and other Law Acts of Organization for Security and Cooperation in Europe about small arms and light weapons.

It is also important to note that the agreement On The Cooperation Of Member Countries Of The Commonwealth Of Independent States In Combating Illicit Trafficking In Firearms, Ammunition, Explosives and Explosive Devices has a strong role for the development of national legislation on firearm trafficking [16].

In addition, Ukraine is clearly fulfilling the decrees adopted by the Security Council, Organization for Security and Co-operation in Europe and within the Wassenaar agreement, United Nations Security Council resolutions, implementing the sanctions regime is the governing doctrine in deciding the relevant laws and regulations. It gives our country the opportunity to be in line with the leading countries of the international community in matters of legal regulation of firearms turnover.

One of the recent Directives is 2008/51/EC of The European Parliament and of the Council of 21 May 2008, which is amending Council Directive 91/477/EEC on control of the acquisition and possession of weapons. Actually, it is important, that in article 4 of the Directive 2008/51/EC it states The Member States shall, by 31 December 2014, ensure the establishment and maintenance of a computerized data filing system, either a centralized 
system or a decentralized system which guarantees to authorized authorities access to the data-filing systems in which each firearm subject to this Directive shall be recorded. This filing system shall record and maintain for not less than 20 years each firearm's type, make, model, caliber and serial number, as well as the names and addresses of the supplier and the person acquiring or possessing the firearm [10].

Member States shall ensure either that any firearm or part placed on the market has been marked and registered in compliance with this Directive, or that it has been deactivated.

For the purpose of identifying and tracing each assembled firearm, Member States shall, at the time of manufacture of each firearm, either:

a) require a unique marking, including the name of the manufacturer, the country or place of manufacture, the serial number and the year of manufacture (if not part of the serial number). This shall be without prejudice to the affixing of the manufacturer's trademark. For these purposes, the Member States may choose to apply the provisions of the Convention of 1 July 1969 on Reciprocal Recognition of Proof marks on Small Arms; or

b) maintain any alternative unique user-friendly marking with a number or alphanumeric code, permitting ready identification by all States of the country of manufacture.

The marking shall be affixed to an essential component of the firearm, the destruction of which would render the firearm unusable [10].

In our opinion, above-stated requirements of the Directive 2008/51/EC will be really effective for prevention if illegal firearms turnover.

For complete and comprehensive crime prevention, investigation and disclosure of information about a crime and those involved in it has a great importance in Ukraine. One of the information sources necessary for the investigation is criminalistics account, produced by the police of Ukraine. Criminalistics account is a scientific system of registration of certain facilities and identification signs for the prevention and disclosure of crimes, investigation and identification of objects taken into account. This system and its usage are based on strict adherence to the rule of law. Certificates of facilities doing criminalistics account, after their accession to the case are used as evidence in legal proceedings (Article 65 of the Criminal Code of Ukraine). Accounting firearms is regulated 
by the Order "On the approved instructions for the functioning of criminalistics account of expert service of the MIA" from 10.09.2009 № 390 [6, 13].

Conclusion An important place in this position holds the Forensic expert service of the Ministry of Internal Affairs of Ukraine, since its duties include prevention as well as direct assistance to disclose crimes. Also one of the main forms of interaction of Forensic expert service with other departments of Internal Affairs is conducting criminalistics account. Besides, the expert criminal divisions conduct ballistic expertise and research.

Currently, with the establishment of effective and lawful Firearms Act and development of Forensic Identification using criminalistics account is the way of successfully combating criminal manifestations in our society and, consequently, ensuring the constitutional rights of citizens.

\section{References}

1. Bilenchuk P.D. Arms Research: The Legal Basis of the Circulation of Firearms. Comparative analysis of domestic and foreign legislation: Ukraine. Europe. World / P. D. Bilenchuk, A. V. Kofanov, O. F. Suliava; edited by prof. P.D. Bilenchuk. - K.: International agency "BeeZone", 2004. - 464 p.

2. Weapon for permission and under control: interview with the Head of the Permit System and licensed by the DG of the Ministry of Internal Affairs Valentin Medved / [compiled by T. Chepelskaya] // Weekly of the Ministry of Internal Affairs of Ukraine "by the name of the Law". - K.: Press of Ukraine, 2009. - No. 42. - P. 10.

3. Kofanov A.V. Adoption of the Law of Ukraine "About Weapons" as a Component of Improvement of Criminal Law / A.V. Kofanov // Problems of Criminal Legislation of Ukraine. Journal of the Lugansk State University of Internal Affairs. - Lugansk: Luhansk University of Internal Affairs, 2007. - Special. vip - P. 110-112.

4. The Constitution of Ukraine. URL: http://zakon.rada.gov.ua/cgibin/laws/main.cgi?nreg=254\%EA\%2F96-\%E2\%F0

5. The Criminal Code of Ukraine: as of February 16, 2010 URL: http://zakon.rada.gov.ua/cgi-bin/laws/main.cgi?nreg=2341-14

6. About an approval of the Instruction on the formation of the use of forensic records of the Forensic Center of the Ministry of Internal Affairs of Ukraine: Order of the Ministry of Internal Affairs of Ukraine dated September 10, 2009 No. 390. URL: http://zakon.rada.gov.ua/cgi-bin/laws/main .cgi? nreg = z0963-09

7. About an approval of the Instruction on the procedure for the manufacture, acquisition, storage, accounting, transportation and use of firearms, pneumatic and cold weapons, domestic production equipment for the shooting of cartridges equipped with rubber or similar non-lethal metal shells of the same properties, and also the specified cartridges, as well as Ammunition for weapons and explosives: Order of the Ministry of Internal Affairs of Ukraine No. 622 dated August 21, 1998 URL: http://zakon.nau.ua/doc/?uid=1036.449.0\&nobreak=1 
8. State and structure of crime in Ukraine Statistics of the Ministry of Internal Affairs of Ukraine for 2007-2018. URL: http://212.1.76.10/mvs/doccatalog/document?id=170310

9. State and structure of crime in Ukraine: Statistics of the Ministry of Internal Affairs of Ukraine for 2008-2019. URL: http://mvsinfo.gov.ua/statistika/StatistikaMVS_2009.xls

10. Directive 2008/51/EC of the European Parliament and of the Council of 21 May 2008. URL:

http://eur-

lex.europa.eu/LexUriServ/LexUriServ.do?uri=OJ:L:2008:179:0005:0011:EN:PDF

11. Criminal law and forensic classification of smooth-bore firearms. URL: https://doi.org/10.32370/IAJ.2079

12. URL: http://elar.naiau.kiev.ua/jspui/handle/123456789/10710

13. Legal regulation of the firearms circulation in the countries of the former Warsaw treaty and the Soviet Union. URL: https://doi.org/10.25313/2520-2308-2019-2-4852

14. Forensic experts 'mistakes: theoretical and practical aspects. URL: https://doi.org/10.32370/online/2019_03_25_2

15. Aviation flights safety as an element of national security. URL: https://doi.org/10.25313/2617-572x-2019-1-4868

16. Bureau of alcohol, tobacco, firearms and explosives, (atf) USA: genesis. URL: https://doi.org/10.25313/2520-2294-2019-4-4855 